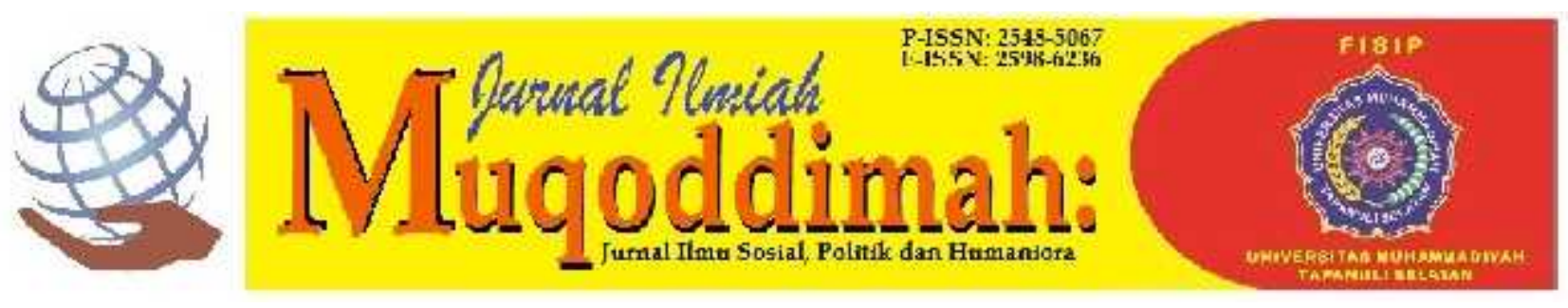

\title{
Pemetaan Sektor Unggulan Untuk Mendukung Pertumbuhan Ekonomi di Kabupaten Pegunungan Arfak Provinsi Papua Barat
}

\author{
Muhammad Gilang Gumilar ${ }^{1)}$, Nur Aini Yuniyarti ${ }^{2)}$ \\ Ekonomika Terapan, Departemen Ekonomika dan Bisnis, Sekolah Vokasi Universitas Gadjah Mada \\ Gedung SV UGM, Sekip Unit 1 Catur Tunggal, Depok Sleman Yogyakarta, Indonesia \\ muhammad.g@mail.ugm.ac.id \\ nur_ay@mail.ugm.ac.id
}

\begin{abstract}
Abstrak
Kabupaten Pegunungan Arfak di Provinsi Papua Barat, merupakan daeah otonom yang baru dibentuk dengan berbagai potensi sektor ekonomi yang dapat dikembangankan untuk mendukung pertumbuhan ekonomi dan pembangunan daaerah. Penelitian ini bertujuan untuk mengetahui sektor unggulan/basis maupun tidak kompetitif/non-basis untuk mendukung pertumbuhan ekonomi. Jenis atau pendekatan yang digunakan dalam penelitian ini yaitu kuantitatif. Data yang yaitu data sekunder yang bersumber dari Badan Pusat Statistika (BPS). Data yang dianalisis yaitu Produk Domestik regional Bruto (PDRB) atas dasar harga konstan tahun 2010 Kabupaten Pegunungan Arfak dan Provinsi Papua barat tahun 20142019. Adapun teknik analisis yang digunakan yaitu Location Quotient (LQ) dengan alat analisis Microsoft Excel.Adapun hasil dari penelitian ini, yaitu terdapat 6 sektor unggulan yang berkontribusi cukup signifikan terhadap perekonomian Kabupaten Pegunungan Arfak. Kemudian, 11 sektor lainnya tidak kompetitif/unggulan karena belum mampu memenuhi kebutuhan daerah dan berkontribusi terhadap pertumbuhan ekonomi. Pemerintah Daerah Kabupaten pegunungan Arfak diharapkan mampu mengelola dan meningkatkan kualitas sektor yang tidak kompetitif/non-basis .
\end{abstract}

Kata kunci: pertumbuhan ekonomi, location quotient, sektor unggulan

\begin{abstract}
The Arfak Mountains Regency at West Papua Province is a newly formed autonomous state with a variety of potential economic sectors that can be developed to support the economic growth and development of the regency. This research aims to determine the superior/base or non-competitive sectors to support economic growth. The type or approach used in this research is quantitative. Data that is a secondary data sourced from the Statistical Central Agency (BPS). The Data analyzed is gross regional domestic product (PDRB) on the basis of constant price of 2010 regency of Arfak Mountains and West Papua Province on 2014-2019. The analysis techniques used are Location Quotient (LQ) with Microsoft Excel analysis tools. The result of this study, namely, there are 6 superior sectors that contribute quite significantly to the economy of the Arfak Mountain Regency. Then, 11 other sectors are not competitive/flagship because they have not been able to meet the needs of the region and contribute to economic growth. The local government of Arfak Mountain District is expected to manage and improve the quality of noncompetitive/nonbase sectors.
\end{abstract}

Keywords: economic growth, location quotient, superior secto 


\section{PENDAHULUAN}

Pembangunan ekonomi daerah yaitu, suatu proses yang dilakukan pemerintah dan masyarakat sekitar dalam mengelola potensi ekonomi dan membentuk pola kemitraan antara sektor pemerintah dengan swasta dalam menciptakan lapangan kerja dalam membantu perkembangan pertumbuhan ekonomi daerah. Hal tersebut dapat diwujudkan apabila pemerintah dan masyarakat memiliki inisiatif yang tinggi dalam mengelola sumber daya yang mampu menaksir potensi yang diperlukan dalam proses pembangunan (Arsyad, 1999)

Potensi sektor ekonomi di setiap daerah harus dikelola dan dimanfaatkan dengan optimal dalam menunjang pemenuhan kebutuhan daerah.pengembangan sektor unggulan dapat memberikan kontrbusi terhadap peningkatan pertumbuhan ekonomin daerah. Akan tetapi, masih banyak daerah di Indonesia dengan tingkat pertumbuhan ekonomi yang rendah yang disebabkan oleh rendahnya pengelolaan sektor ekonomi unggulan.

Berdasarkan Master Plan koridor pembangunan Nasional Indonesia, Papua, Papua Barat, Maluku, dan Maluku Utara dikelompokkan dalam koridor VI yang difokuskan pada sektor pangan dan energi. Sektor pangan memberikan kontribusi terhadap peningkatan kebutuhan ekonomi masyarakat di Indonesia. Oleh karena itu, Papua Barat memberikan kontrbusi yang signifikan.

Kabupaten Pegunungan Arfak yaitu daerah otonom baru di Provinsi Papua Barat dengan luas lahan mencapai $2.773,74 \mathrm{~km}^{2}$ dan jumlah penduduk kurang lebih 26.735 Jiwa yang tersebar di beberapa 166 kampung. Selain itu, hasil penelitian Wambrau (2015), pada wilayah Kabupaten Pegunungan Arfak terdapat tanaman buah-buahan, ubi-ubian, sayuran, dan tanaman jangka panjang.

Mulyadi (2012) menjelaskan bahwa sektor pertanian di wilayah Kabupaten Pegunungan Arfak dapat menjadi sektor unggulan yang bisa membantu dalam peningkatan PDRB. Hal tersebut ditunjang dengan topografinya berada pada dataran tinggi yaitu lebih dari $2000 \mathrm{mdpl}$ (meter diatas permukaan laut).

Tabel 1

Total PDRB Kabupaten Pegunungan Arfak tahun 2014-2019 berdasarkan harga konstan 2010

\begin{tabular}{l|l}
\hline Lapangan Usaha & Total PDRB \\
\hline Pertanian, Kehutanan, dan Perikanan & Rp 319.907.000.000 \\
Pertambangan dan Galian & Rp. 1.981 .800 .000 \\
Industri Pengolahan & Rp. 0 \\
Pengadaan Listrik dan Gas & Rp. 1.304 .300 .000 \\
Pengadaaan Air, Sampah, dan Daur Ulang & Rp. 0 \\
Kontruksi & Rp. 54.036 .000 .000 \\
Perdagangan Besar dan Eceran; Reparasi Mobil & Rp. 630.430.000 \\
\hline Lapangan Usaha & Total PDRB \\
\hline Transportasi dan Pergudangan & Rp. 392.690.000 \\
Penyediaan Akomodasi Makan dan Minum & Rp. 847.890.000 \\
Informasi dan Komunikasi & Rp. 336.170 .000 \\
Jasa Keuangan dan Asuransi & Rp. 482.990.000
\end{tabular}


Real estate Jasa Perusahaan

Administrasi Pemerintahan, Pertahanan, dan Jaminan sosial

Jasa Pendidikan

Jasa Kesehatan dan Kegiatan Sosial

Jasa Lainnya

Total PDRB 2014-2019 semua sektor

Sumber : data Badan Pusat Statistik (diolah)

Berdasarkan Tabel 1 nilai PDRB terbesar ada pada sektor Pertanian, kehutanan, dan perikanan yaitu Rp. 319.907.000.000, terbesar kedua sektor Administrasi pemerintahan, pertahanan dan Jaminan sosial sebesar Rp. 303.012.000.000 PDRB terkecil yaitu sektor Industri Pengolahan, Pendgadaan Air/Daur ulang, dan Jasa Perusahaan.

Kelemahan dari Kabupaten Pegunungan Arfak yaitu belum diketahui potensi dari sektor ungulan dan non-unggulan yang disyaratkan dalam pembangunan wilayah berbasis komoditas unggulan, efesiensi, danpelaku pembangunan daerah (Hati dan Sardjito, 2014). Adapun permasalahan lainnya, hasil forum Ekonomi Kementerian Keuangan (FEKK) menjelaskan bahwa tingkat kemiskinan di Kabupaten Pegunungan Arfak pada tahun 2017 yaitu 39,23\% tertinggi di Provinsi Papua Barat.Hal tersebut dapat diimbangi dengan nilai PDRB Kabupaten Pegunungan Arfak pada tahun 2019 meningkat yang dipengaruhi oleh peningkatan produksi di beberapa lapangan usaha yang terbebas dari inflasi.

Nilai PDRB berdasarkan harga konstan 2010, mencapai 137,86 miliar rupiah tahun 2019. Angka tersebut naik dari 132,45 miliar rupiah dari tahun 2018. Namun, selama tahun 2019 terjadi pertumbuhan ekonomi sebesar 4,08 persen, lebih rendah jika dibandingkan dengan pertumbuhan ekonomi pada tahun 2018 yaitu sebesar 9,87 persen (Badan Pusat Satistika, 2020).

Potensi unggulan sektor ekonomi harus dikelola dengan baik dan dikembangkan untuk mengurangi ketimpangan ekonomi wilayah (Baransano et al, 2016). Teknik analisis Location Quotient (LQ) merupakan salah satu indikator dalam mengetahui sektor unggulan maupun non-unggulan. Analisis LQ menyajikan perbandingan relatif kemampuan sektor di daerah tertentu dengan kemampuan sektor yang sama pada wilayah yang lebih luas (Hendarto, 2000).

Dengan demikian, tujuan penelitian ini adalah untuk mengetahui sektor unggulan maupun non-unggulan untuk mendorong pertumbuhan ekonomi di Kabupaten Pegunungan Arfak Provinsi Papua Barat.

Ada beberapa teori yang digunakan dalam penelitian ini yaitu, pertumbuhan ekonomi, location quotient, dan sektor unggulan.

\section{Pertumbuhan ekonomi}

Pengukuran pertumbuhan ekonomi secara konvensional biasanya dengan menghitung peningkatan presentase dari Produk Domestik Bruto (PDB). PDB mengukur pengeluaran total dari suatu perekonomian terhadap berbagai barang dan jasa yang baru diproduksi pada suatu saat atau tahun serta pendapatan total yang diterima dari adanya seluruh produksi barang dan jasa tersebut atau secara lebih rinci, PDB adalah 
nilai pasar dari semua barang dan jasa yang diproduksi di suatu negara dalam kurun waktu tertentu (Mankiw, 2001:126).

Pertumbuhan biasanya dihitung dalam nilai riil dengan tujuan untuk menghilangkan adanya inflasi dalam harga dan jasa yang diproduksi sehingga PDB riil mencerminkan perubahan kuantitas produksi. Untuk mengetahui pertumbuhan ekonomi regional, digunakanlah data Produk Domestik Regional Bruto (PDRB) dimana PDRB dapat didefinisikan sebagai nilai barang dan jasa akhir yang dihasilkan oleh sistem perekonomian di suatu wilayah atau daerah dalam kurun waktu tertentu. Sehingga PDRB merupakan suatu ukuran untuk melihat aktivitas perekonomian suatu daerah. Secara teori, PDRB tidak dapat dipisahkan dari Produk Domestik Bruto (PDB).

2. Locaton Quotient (LQ)

Analisis LQ digunakan untuk menentukan sektor unggulan (basis) maupun potensial (non-basis) dengan menghitung perbandingan besarnya nilai sektor di daerah yang bersangkutan terhadap besarnya peranan sektor wilayah yang lebih tingi atau luas. (Tarigan, 2005). Adapun rumus LQ dalam menetukân sektor basis maupun non-basis yaitu sebagai berikut :

Keterangan :

$$
L Q=\frac{Y \frac{i k}{t k}}{Y \frac{i p}{t p}}
$$

$\mathrm{LQ}=$ Nilai $L Q$ suatu komoditas

$\mathrm{Y}$ ik = PDRB komoditas I di kabupaten/kota $\mathrm{X}$

$Y$ tk $=$ Total PDRB semua komoditasdi kabupaten/kota $X$

$Y$ ip $=$ PDRB komoditas I diProvinsi $X$

$Y$ tk $=$ Total PDRB semua komoditas I di Provinsi $X$

Jika nilai $L Q>1$ maka komoditas sektor I basis atau unggulan, sehingga sektor tersebut mampu memenuhi kebutuhan barang dan jasa yang ada di Kabupaten yang bersangkutan maupun di luar daerah tersebut.

Nilai LQ $<1$ menunjukkan sektor non-basis, kondisi komoditas sektor I di Kabupaten/kota berkontribusi kecil daripada komoditas yang sama di daerah tersebut dalam pembentukan PDRB. Komoditas tidak mampu memenuhi kebutuhan daerah maupun diluar daerah Kabupaten tersebut.

Kemudian, nilai $L Q=1$ menunjukkan komoditas I self sufficient, kabupaten/kota mampu memenuhi kebutuhan barang dan jasa dengan hasil kegiatan ekonomi yang ada di daerah tersebut.

\section{Sektor Unggulan}

Sektor unggulan yaitu sektor yang mampu mendorong pertumbuhan ekonomi atau perkembangan sektor lainnya dilihat dari nilai PDRB (Widodo, 2006). Sektor unggulan atau basis sangat penting dalam pembangunan ekonomi wilaya, tidak hanya mengacu pada lokasi geografis, melainkan sektor yang menyebar dalam perekonomian yang dapat menggerakkan ekonomi keseluruhan.

Sambodo (dalam Firman, 2007), ciri sektor unggulan yaitu :

a. Memiliki laju pertumbuhan ekonomi yang tinggi.

b. Nilai penyebaran relatif besar dan memiliki keterkaitan antar sektor tinggi maupun rendah.

C. Mampu menciptakan nilai tambah yang tinggi. 
Presentase kontribusi sektor unggulan terhadap pertumbuhan ekonomi dapat di hitung dengan perbandingan nilai sektor I dengan total keseluruhan nilai sektor pada tahun yang bersangkutan.

\section{METODE}

Metode yang digunakan dalam penelitian ini yaitu pendekatan kuantitatif. Penelitian yang menggunakan metode atau pendekatan kuantitatif memiliki tujuan untuk uji teori objektif, menguji hubungan antar variabel dengan menggunakan data statistik (Creswell, 2014).

Jenis data yang digunakan yaitu data sekunder yang bersumber dari website BPS Provinsi Papua Barat dan Kabupaten Pegunungan Arfak. Data yang digunakan yaitu data PDRB menurut Lapangan Usaha Provinsi Papua Barat dan Kabupaten Pegunungan Arfak tahun 2014-2019 berdasarkan harga konstan tahun 2010. Teknik analisis yang digunakan yaitu Location Quotient(LQ) dengan alat analisis Microsoft Excel.Hasil dan pembahasan.

Adapun rumus $L Q$ yang digunakan dalarr penelitian ini, yaitu :

Keterangan :

$$
\mathrm{LQ}=\frac{\frac{\gamma t k}{t k}}{\gamma \frac{i p}{t p}}
$$

$L Q=$ Nilai $L Q$ suatu komoditas

$\mathrm{Y}$ ik = PDRB komoditas I di Kabupaten Pegunungan Arfak

$\mathrm{Y}$ tk $=$ Total PDRB semua komoditasdi Kabupaten Pegunungan Arfak

$Y$ ip $=$ PDRB komoditas I di Provinsi Papua Barat

Y tk $=$ Total PDRB semua komoditas I di Provinsi Papua Barat

\section{HASIL DAN PEMBAHASAN}

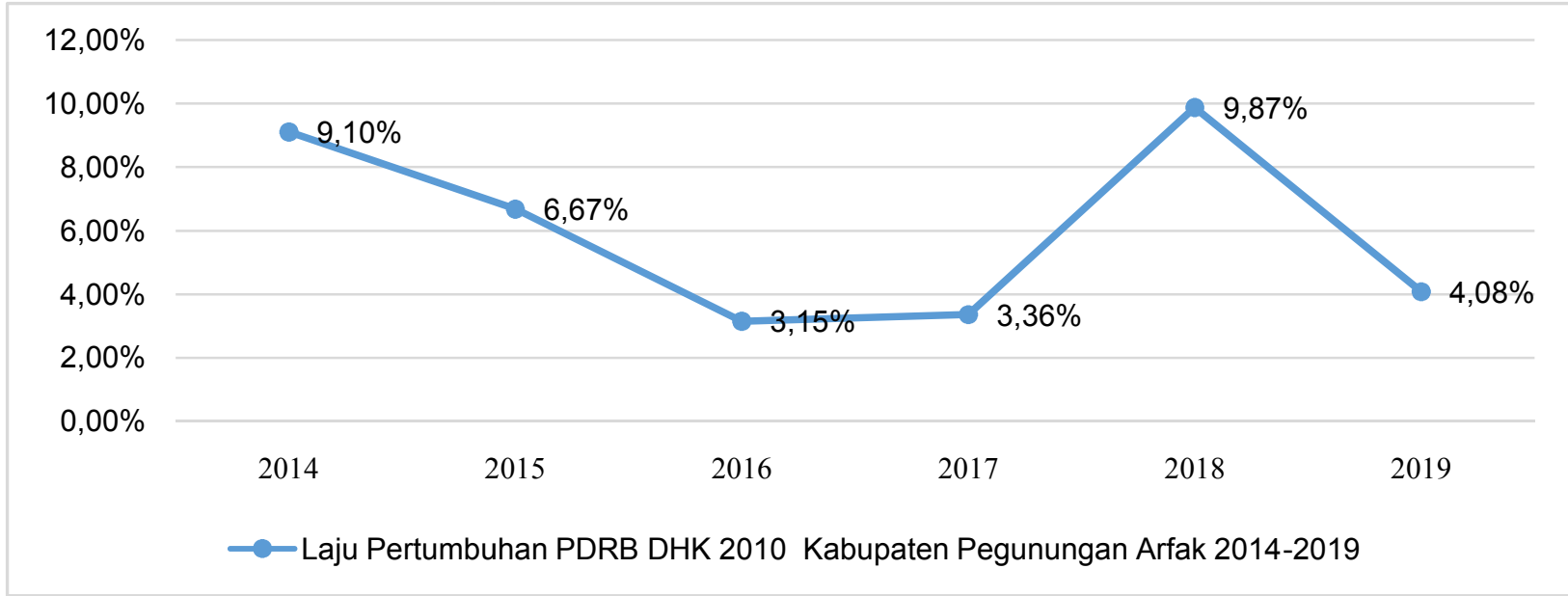

Grafik 1 Laju Pertumbuhan PDRB DHK 2010 Kabupaten Pegunungan Arfak Provinsi Papua Barat tahun 2014-2019 Sumber : data Badan Pusat Statistik (diolah) 
Berdasarkan grafik 1, tingkat pertumbuhan ekonomi Kabupaten Pegunungan Arfak, dilihat dari nilai presentase PDRB pada tahun 2014-2019 mengalami penurunan maupun kenaikan yang cukup signifikan. Pada tahun 2014 hingga 2016 tingkat pertumbuhan ekonomi mengalami penurunan mencapai nilai 3,15\% ditahun 2016. Kemudian, pada tahun 2017 terjadi sedikit kenaikan sebesar $0,21 \%$ dan tahun 2018 kembali naik yang sangat signifikan sebesar $6,51 \%$, sehingga mencapai angka 9,87\%. Namun, ditahun 2019 nilai pertumbuhan ekonomi 4,08\% karena mengalami penurunan sebesar $5,79 \%$.

Adapun hasil perhitungan analisis Location Quotient Kabupaten Pegunungan Arfak Provinsi Papua Barat adalah sebagai berikut :

Tabel 2

Hasil Perhitungan Analisis Location Quotient

\begin{tabular}{l|l|l|l}
\hline No & \multicolumn{1}{|c|}{ Lapangan Usaha } & \multicolumn{1}{c}{ Rata-rata LQ } & \multicolumn{1}{c}{ Hasil } \\
\hline 1 & Pertanian, Kehutanan, dan Perikanan & 4,28461081 & Basis \\
2 & Pertambangan dan Galian & 0,01360978 & Non-basis \\
3 & Industri Pengolahan & 0 & Non-basis \\
4 & Pengadaan Listrik/Gas & 4,97265469 & Basis \\
\hline No & \multicolumn{1}{|c}{ Lapangan Usaha } & Rata-rata LQ & \multicolumn{1}{c}{ Hasil } \\
\hline 5 & Pengadaaan Air/Sampah/DU & 0 & Non-basis \\
6 & Kontruksi & 0,60903589 & Non-basis \\
7 & Perdagangan Besar dan Eceran; Reparasi Mobil & 0,01321974 & Non-basis \\
8 & Transportasi dan Pergudangan & 0,02113719 & Non-basis \\
9 & Penyediaan Akomodasi Makan dan Minum & 0,21080761 & Non-basis \\
10 & Informasi dan Komunikasi & 0,02537445 & Non-basis \\
11 & Jasa Keuangan dan Asuransi & 0,04828905 & Non-basis \\
12 & Real estate & 0,44624760 & Non-basis \\
13 & Jasa Perusahaan & 0 & Non-basis \\
14 & Administrasi Pemerintahan, Pertahanan, dan & 4,87220759 & Basis \\
& Jaminan sosial & 1,54372721 & Basis \\
15 & Jasa Pendidikan & 1,85960205 & Basis \\
16 & Jasa Kesehatan dan Kegiatan Sosial & 1,29772984 & Basis \\
\hline
\end{tabular}

Sumber : data Badan Pusat Statistik (diolah)

Berdasarkan Tabel 2, sektor unggulan atau basis pada Kabupaten Pegunungan Arfak Provinsi Papua Barat yaitu, sektor pertanian, kehutanan, dan perikanan dengan nilai LQ 4,3 >1, sektor tersebut sudah mampu memenuhi kebutuhan masyarakat dan bisa memenuhi kebutuhan daerah lainnya di luar Kabupaten Pegunungan Arfak. Hal tersebut sejalan dengan nilai PDRB dari sektor Pertanian,kehutanan, dan perikanan pada tahun 2014-2019 memberikan kontrbusi terbesar 44\% pada pertumbuhan ekonomi dengan nilai PDRB Rp 319.907.000.000.

Kemudian, sektor pengadaan listrik dan gas dengan nilai LQ $4.972654691>1$ menunjukkan sektor tersebut basis atau unggulan seperti halnya dengan sektor 
pertanian, kehutanan, dan perikanan. Sektor pengadaan listrik dan gas memberikan kontrbusi terhadap petumbuhan ekonomi Kabupaten Pegunungan Arfak sebesar 7\%.

Adapun sektor unggulan atau basis lainnya, yaitu administrasi pemerintahan, pertahanan dan jaminan sosial; jasa pendidikan; jasa kesehatan dan kegiatan sosial; dan jasa lainnya. Nilai LQ sektor secara berturut-turut lebih dari satu, yaitu 4,9, 1,5, 1,9, dan 1,3. Kontribusi terbesar dari ketiga sektor tersebut yaitu, administrasi pemerintahan dengan nilai presentase kontribusi $42 \%$. Selain itu, presentase kontribusi jasa pendidikan, jasa kesehatan, dan jasa lainnya, yaitu $4 \%, 1 \%$, dan $0,003 \%$.

Sektor non-basis atau tidak kompetitif yaitu, pertambangan dan penggalian, industri pengolahan, pengadaan air dan daur ulang, kontruksi, perdagangan besar dan reparasi kendaraan, transportasi dan pergudangan, penyediaan makanan dan minum, informasi komunikasi, jasa keuangan dan asuransi, real estate, dan jasa perusahaan. Sektor tersebut memiliki nilai $L Q<1$, sehingga tidak bisa memenuhi kebutuhan Kabupaten Pegunungan Arfak Provinsi Papua Barat maupun daerah lainnya secara maksimal dengan kontrbusi terhadap pertumbuhan ekonomi sangat rendah.

Penelitian ini sejalan dengan penelitian Sagrim et al (2017) menyatakan bahwa salah satu sektor unggulan, yaitu Pertanian merupakan sektor prime mover di Kabupaten Pegunungan Arfak karena memberikan kontribusi terbesar dalam pembangunan ekonomi wilayah di Kabupaten Pegunungan Arfak. Kontribusi terbesar dari sektor pertanian maupun perkebunan didukung oleh sumber daya lahan dan peran keluarga petani dalam mengupayakan komoditas pertanian meliputi sub sektor tanaman pangan, holtikultura, dan perkebunan.

Kemudian, Hasil analisis SWOT dapat dijelaskan bahwa faktor modal (Suratiyah, 2008) akan memperkuat pembangunan pertanian di Kabupaten Pegunungan Arfak dalam ketersediaan lahan pertanian dan komoditi unggulan di setiap distrik. Komoditi unggulan pertanian adalah seperti tanaman pangan, hortikultura dan perkebunan. Selain itu, disediakannya mini ranch bagi program pembangunan peternakan.

\section{SIMPULAN DAN SARAN}

Pertumbuhan ekonomi Kabupaten Pegunungan Arfak pada tahun 2014-2019 menglami kenaikan dan penurunan. Tingkat laju pertumbuhan tertinggi terjadi pada tahun 2018 sebesar $9.87 \%$. Ada 6 sektor unggulan yang berkontribusi cukup signifikan terhadap perekonomian Kabupaten Pegunungan Arfak. Kemudian, 11 sektor lainnya tidak kompetitif/unggulan karena belum mampu memenuhi kebutuhan daerah dan berkontribusi terhadap pertumbuhan ekonomi.

Adapun saran berdasarkan kesimpulan di atas, Pemerintah Daerah Kabupaten Pegunungan Arfak diharapkan mampu menjaga kestabilan nilai kontribusi dan kualitas dari sektor unggulan, sehingga dapat menunjang pemenuhan kebutuhan daerah secara optimal. Selain itu, sektor yang tidak komptetitif diharapkan bisa dikelola dengan baik oleh Pemerintah Daerah Kabupaten Pegunungan Arfak dengan meningkatkan total PDRB dari sektor tersebut untuk mendorong pertumbuhan ekonomi dan pembangunan daerah lebih baik pada tahun berikutnya, sehingga kualitas layanan publik dan penyediaan sarana prasana akan meningkat. 


\section{DAFTAR PUSTAKA}

Arsyad, Lincoln. 1999. Pengantar Perencanaan dan Pembangunan Ekonomi Daerah. Yogyakarta : BPFE

Badan Pusat Statistik. 2020. Produk Domestik Bruto Kabupaten Pegunungan Arfak menurut Lapangan Usaha 2015-2019. Provinsi Papua Barat : Badan Pusat Statisti

Baransano MA, Putri EIK, Achzani NA, Kolopaking L. 2016. Peranan Sektor Unggulan Sebagai Salah Satu Faktor dalam mengurangi Ketimpanan Pembangunan Wilayah di Provinsi Papua Barat. Jurnal Perencanaan Wilayah dan Kota. 27(2): 119-136. http://doi.org/cfz7

Creswell, J. (2014). Research design : qualitative, quantitative, and mixed methods approaches (Vol. 4th ed Thousand Oaks). California: SAGE Publication.

Firman, Achmad. 2007. Analisis dampak Investasi Sektor Peternakan Terhadap Perekonomian di Jawa Tengah.http://www.Pustaka.Unpad.ac.id

Hati IP, Sardjito. 2014. Arahan Pengembangan Komoditas Unggulan di Kabupaten Muara Enim Sumatera Selatan. Jurnal Teknik Pomits. 3(2): C230-C234

Hendarto RM. 2000. Analisis potensi daerah dalam pembangunan ekonomi. Makalah Diklat. Semarang (ID): Universitas Diponegoro.

Mulyadi. 2012. Budaya pertanian Papua; Perubahan Sosial dan Strategi Pemberdayaan Masyarakat Arfak. Yogyakarta (ID): PT Karta Media.

Mankiw, N. Gregory. 2006. Teori Ekonomi Makro. Edisi Keempat. Terjemahan. Jakarta: Penerbit Erlangga.

Tarigan, Robinson. 2005. Ekonomi Regional Teori dan Aplikasi. Jakarta : PT.Bumi Aksara.

Sagrim M, Sumule Al, lyai DJ, Baransano M. 2017. Potensi Unggulan Komoditas Pertanian pada Daerah Dataran Tinggi Kabupaten Pegunungan Arfak, Papua Barat $\begin{array}{lllll}\text { Jurnal IImu Pertanian Indonesian (JIPI). } & \text { I22(3):141- }\end{array}$ 146.http://journal.ipb.ac.id/index.php/JIPI DOI: 10.18343/jipi.22.3.141

Suratiyah. 2008. Ilmu Usahatani. Penebar Swadaya. Jakarta.

Wambrauw L, Sonbait LY, Syaranamual S, Ungirawalu A, Runtuboi YY. 2015. Profil pertanian, peternakan, perkebunan dan perikanan di kabupaten Pegunungan Arfak Tahun 2015. [Report]. Tidak Dipublikasikan. Manokwari (ID): Pemda Kabupaten Pegunungan Arfak dan Universitas Papua

Widodo, Tri. 2006. Perencanaan Pembangunan : Aplikasi Komputer. Yogyakarta: UPP STIM YKPN. 